\section{Oswaldo Cruz e a controvérsia da sorologia*}

\section{Oswaldo Cruz and the serology controversy}

Jorge Augusto Carreta

Professor da Faculdade de Ciências Sociais/ Pontifícia Universidade Católica de Campinas.

Rodovia D. Pedro I, km 136

13086-900 - Campinas - SP

jorgecarreta@yahoo.com.br

Recebido para publicação em fevereiro de 2009.

Aprovado para publicação em outubro de 2010.
CARRETA, Jorge Augusto. Oswaldo Cruz e a controvérsia da sorologia. História, Ciências, Saúde - Manguinhos, Rio de Janeiro, v.18, n.3, jul.-set. 2011, p.677-700.

\section{Resumo}

A fim de analisar a discussão sobre a eficácia do soro antipestoso produzido pelo Instituto de Manguinhos no começo do século XX, faz-se breve apreciação da atuação de Oswaldo Cruz à frente da Diretoria de Saúde Pública e, em seguida, aborda-se a polêmica propriamente por meio da sua correspondência com Miguel Pereira, Vital Brazil, Chapot Prévost e Francisco Fajardo. Evidencia-se, nessas cartas, o grau de incerteza e experimentação que marcava a bacteriologia no Brasil daquele momento, embora, publicamente, ela se apresentasse como conhecimento seguro e inquestionável. Mostra-se como argumentos de natureza extracientífica interferem no desenvolvimento de pesquisas e na aceitação dos produtos médicos.

Palavras-chave: controvérsias científicas; sorologia; soro antipestoso; microbiologia; Brasil.

\section{Abstract}

This analysis of the discussion surrounding the efficacy of the plague serum produced by Manguinhos Institute in the early twentieth century begins with an overview of Oswaldo Cruz's service as head of the Public Health Directorship (Diretoria de Saúde Pública). The controversy itself is then addressed, through an exploration of correspondence exchanged by physicians Oswaldo Cruz, Miguel Pereira, Vital Brazil, Chapot Prévost, and Francisco Fajardo. Their letters reveal how bacteriology in Brazil was then marked by uncertainty and experimentation, even while this field of knowledge publicly touted itself as safe and incontestable. The article shows how arguments of an extra-scientific nature interfere with both research development and the acceptance of medical products.

Keywords: scientific controversies; serology; plague serum; microbiology; Brazil. 
Jorge Augusto Carreta

$\mathrm{O}$ objetivo deste artigo é analisar as disputas em torno do emprego de soros curativos nos primeiros anos do século $\mathrm{XX}$, pelos médicos envolvidos com o Instituto de Manguinhos. Para a análise desses conflitos, a literatura sobre controvérsias científicas fornece importantes conceitos que permitem ampliar a compreensão das dificuldades relativas à aceitação, no período tratado, da teoria microbiológica.

Os estudos sobre controvérsias datam da década de 1970, momento no qual vários autores procuravam entender o comportamento da comunidade científica e assinalar as contingências que marcam o processo de construção do conhecimento científico (Velho, Velho, 2002). Como assinala Helga Nowotny (1975, p.93, citado em Mendelsohn, 1987, p.37), "as controvérsias são parte integrante da produção coletiva do conhecimento; desacordos sobre conceitos, métodos, interpretações e aplicações são a seiva vital da ciência e um dos mais importantes fatores no desenvolvimento científico". Essa literatura está relacionada a amplo e profundo questionamento das bases da atividade científica e nega a possibilidade de uma ciência que estabeleça a 'verdade definitiva' ou 'proposições finais'. Por essa perspectiva, o dissenso deixa de ser considerado algo estranho ao campo científico, e sua presença é qualificada como contínua e essencial. ${ }^{1}$

Segundo McMullin (1987, p.50), a controvérsia científica é disputa pública que ocupa determinado espaço de tempo. Na discussão, argumentos em torno de um ou mais temas são trocados, oralmente ou por escrito, pelas partes, que podem incluir desde dois indivíduos até grupos ou toda a comunidade científica. Cada lado reivindica para si o status de legítima cientificidade, isto é, afirma que seus argumentos representam os verdadeiros valores da ciência e que seus resultados foram obtidos pelo uso dos 'métodos' corretos. E acrescenta que quem, porventura, não alcançar resultados iguais terá empregado erroneamente os métodos. $\mathrm{O}$ autor divide as controvérsias em epistêmicas e não epistêmicas. As do primeiro tipo referem-se aos conflitos relativos ao conhecimento em si; são os valores assumidos como "relevantes para os méritos do caso que eles [os cientistas] estão debatendo". As não epistêmicas não dizem respeito à discussão científica, não aludem aos 'argumentos de verdade' envolvidos no embate; são fatores não explicitamente mencionados, como pressões políticas, institucionais ou 'eventos casuais' (não previstos). ${ }^{2}$

Ronald Giere (1987, p.126-127), ao definir o que é controvérsia, também alude aos fatores externos à ciência e a enquadra na categoria fenômeno social. Em sua opinião, a noção de controvérsia não pode ser reduzida a "mera categoria lógica", ou seja, à existência pura e simples de proposições ou crenças contrárias. A disputa envolveria substancial quantidade de interação social, transcendendo as questões cognitivas. É por isso - ele observa - que as controvérsias devem ser objeto de estudo dos cientistas sociais.

O que, porém, gera uma controvérsia? De acordo com Giere, a causa imediata é o confronto dos valores dos diferentes grupos sociais. Dorothy Nelkin (1987) afirma que muitas das controvérsias recentes em ciência derivaram da 'crise de autoridade' iniciada na década de 1960, que refletia a diminuição da confiança nas instituições modernas e, particularmente, no poder político constituído. A autora elenca outros fatores específicos que geram as disputas, sendo um deles o "medo do risco" que os novos processos e produtos de ciência e tecnologia poderiam trazer à saúde humana, tais como os conservantes alimentares, a energia nuclear, os novos medicamentos ou o gás freon (também conhecido como CFC). 
Esse medo gera, segundo Nelkin, uma reação por parte de setores da comunidade científica e do público, principalmente porque esses processos ou produtos estão associados a perigos invisíveis, incertos ou não familiares. O caso emblemático citado é o da energia nuclear. Os opositores das usinas nucleares costumam enfatizar o pouco conhecimento sobre os efeitos da exposição à radiação. $\mathrm{O}$ exemplo mais recente é o dos alimentos transgênicos, a respeito dos quais se alega pouca quantidade de estudos conclusivos envolvendo seus eventuais efeitos nocivos à saúde humana e ao meio ambiente.

Outro fator apontado por Nelkin como desencadeador de controvérsias são as possíveis violações de direitos individuais ou a restrição da liberdade de escolha. A disputa surgiria como reação à tentativa, por parte do governo, de impor medidas que, teoricamente, protegeriam os cidadãos. A fluoretação da água para a prevenção de cáries ou a proibição do comércio de substâncias ou remédios nocivos à saúde ilustram esse aspecto da questão.

Sejam quais forem os fatores desencadeadores da controvérsia, é lícito dizer que ela surge, se não totalmente, ao menos em parte, devido à ausência de consenso sobre novas teorias científicas ou sobre produtos delas derivados. O que, entretanto, se entende aqui por consenso? Não é a aceitação universal da totalidade de um conhecimento científico, nem a ausência de disputas a seu respeito. Mesmo em disciplinas há muito consolidadas existe considerável grau de discordância. Neste trabalho defino consenso como a aceitação dos princípios básicos de uma teoria científica. Além de estabelecer os conceitos e métodos fundamentais - que permitem aos cientistas conversar entre si -, essa concordância visa defender a disciplina da intromissão dos não especialistas ou leigos e não precisa obrigatoriamente ser partilhada por toda a comunidade de uma área científica, mas apenas por aquela parte que dispõe de mais prestígio e força para impor seu ponto de vista.

Toda controvérsia tem um fim ou um encerramento. McMullin (1987, p.77-82) sugere três possíveis desfechos: resolução, fechamento (closure) ou abandono. No primeiro caso, a disputa termina porque se alcança concordância sobre a questão em pauta. Os próprios participantes ou a comunidade científica funcionam como árbitros que decidem se o consenso foi alcançado. O autor enfatiza que, na resolução, predominam os fatores epistêmicos ou cognitivos e que a concordância pode não ser total, sem eliminar completamente a força de contra-argumentos, o que atesta a esse consenso um caráter provisório.

No fechamento não só os fatores cognitivos influem; há significativa participação daqueles não relacionados ao conhecimento. Assim, uma controvérsia pode ser encerrada por ação do Estado, que estabelece, por exemplo, a obrigatoriedade de uma medida de saúde pública, como a fluoração da água para combater as cáries ou a vacinação. Não existe, portanto, a resolução, posto que não se estabelecem pontos de consenso entre os cientistas envolvidos. Ao persistir o desacordo entre eles, a contenda pode ser posteriormente reavivada.

A terceira forma de encerramento de uma controvérsia, o abandono, ocorre quando os cientistas envolvidos envelhecem e morrem. Não são encontrados meios para resolver a polêmica e, aos poucos, as gerações seguintes perdem o interesse e abandonam a questão. Nesse caso também não existe resolução, mas nova evidência pode a qualquer momento permitir a obtenção de resposta satisfatória.

No caso da microbiologia brasileira na virada do século XIX para o XX, podemos perceber a dificuldade em construir o consenso e a consequente resolução de alguma contro- 
Jorge Augusto Carreta

vérsia (ou várias). As polêmicas se desenrolaram sobretudo nos periódicos médicos, mas eventualmente foram extravasadas para jornais de grande circulação, que os doutores chamavam de profanos - o que revela o caráter sagrado que pretendiam conferir a sua profissão (cf. Benchimol, 1999; Sampaio, 2002). O debate sobre a vacina, por exemplo, que envolvia bem mais do que uma discussão científica, teve lugar nos principais jornais diários, obrigando os médicos a submeter sua ciência ao crivo dos leigos.

O conhecimento da bacteriologia relacionava-se diretamente a uma importante questão social: o combate às epidemias, fundamental para o projeto civilizatório do país. A atração de imigrantes europeus, ponto relevante desse projeto, era dificultada pelas doenças epidêmicas, em especial a febre amarela. Elas afastavam os estrangeiros e divulgavam a capital brasileira como uma cidade insalubre e perigosa. Paralelamente, os médicos que buscavam descobrir os agentes causadores dessas moléstias e, por conseguinte, sua cura, também estavam empenhados em consolidar sua profissão e impor sua visão de mundo à sociedade e ao Estado. O que lhes faltava, no período aqui abordado, era justamente o consenso em torno das questões básicas da microbiologia. A sucessão de controvérsias e disputas em torno desse conhecimento disseminava a ideia de uma ciência que ainda tinha pouca certeza sobre suas teorias e seus métodos.

Essas controvérsias são reveladas por autores como Sampaio (2002) e Benchimol (1999), que também indicam os caminhos percorridos. Sampaio estudou as diferentes artes de curar durante o Império. Recuperou as polêmicas científicas travadas nas páginas da imprensa carioca e que revelavam a disparidade das práticas terapêuticas. A discussão entre os médicos mostrava a pouca compatibilidade entre seus procedimentos e os conhecimentos que os orientavam. Não eram raros os casos de denúncias de erros que incapacitavam e eventualmente matavam pacientes. Benchimol, por sua vez, focou a atenção em Domingos José Freire, chamado em sua época de Pasteur brasileiro. Freire chegou anunciar, em 1885, a descoberta do microrganismo causador da febre amarela, o Cryptococccus xantogenicus, e de uma vacina que foi aplicada em considerável número de pessoas. O autor esmiuça a trajetória desse cientista (que poderíamos considerar um precursor da medicina experimental no Brasil) e as polêmicas que envolveram a produção de sua vacina, feita a partir de descobertas de suas pesquisas.

As controvérsias aqui apresentadas desdobram-se em vários níveis. O primeiro é o da etiologia das doenças, isto é, de suas causas. Embora a teoria microbiana tivesse muitos adeptos e parecesse caminhar para uma situação de hegemonia, algumas explicações ainda resistiam, como a teoria dos miasmas. Aos poucos ela se enfraqueceu ou se conjugou à teoria microbiana. Em meio aos que operavam segundo a teoria pasteuriana, a controvérsia central residia na identificação do micróbio causador da doença. De sua identificação precisa dependiam o tratamento e sua eventual profilaxia. Esse primeiro nível assume ares de controvérsia cognitiva, embora fatores de natureza extracientífica (ou não epistêmica) estivessem igualmente presentes, já que disputas por espaço, prestígio e patrocínio público se insinuam no debate (Campbell, 1985).

O segundo nível de controvérsias está na aplicação que se faz do conhecimento da microbiologia. A tentativa do médico Oswaldo Cruz de higienizar a cidade do Rio de Janeiro e impor, a partir de 1903, a obrigatoriedade da vacinação oferece rico material para 
análise. Nesses eventos podemos perceber que o conflito entre médicos (e leigos) não se relacionava apenas à existência de teorias ou paradigmas contrários, sobre a bacteriologia. Neles faz-se presente o medo que a população em geral - setores letrados e iletrados manifestava acerca da vacina. As pessoas temiam os efeitos ainda desconhecidos e indesejáveis das inoculações. ${ }^{3}$ Os próprios médicos ainda ignoravam a totalidade das reações oriundas da administração de vacinas e soros. Também havia o medo da disseminação de doenças por meio da vacinação, o que foi muito bem explorado pelos adversários dessa prática.

Outro componente não cognitivo presente no debate era o da liberdade individual. Sustentado por positivistas e liberais, o argumento da liberdade de escolha e da preservação da liberdade individual era constantemente invocado e ecoava o que, desde o final do século XIX, era usado contra quem combatia o curandeirismo. Peça-chave no processo de afirmação profissional, o combate aos curandeiros era igualmente polêmico entre os médicos. Alguns, embora sem endossar tal prática, defendiam o direito de o cidadão escolher a forma de cura que melhor lhe aprouvesse ${ }^{4}$, sem que coubesse aos médicos ou ao Estado constrangê-lo nessa escolha. $\mathrm{O}$ argumento repetia-se na controvérsia sobre a vacinação: independentemente da eficácia ou não do profilático, o direito individual do cidadão deveria ser preservado.

Outro problema, entretanto, se colocava: aqueles que recusavam medidas profiláticas, como a vacina antivariólica ou o tratamento de doenças mediante administração de soros, poderiam disseminar moléstias e colocar em risco toda a sociedade. Nesse caso, segundo Nelkin (1992), manifesta-se a oposição entre os direitos individuais e os objetivos sociais. Porém, ainda caberia perguntar como eram (e são) definidos os objetivos sociais. Essa face não cognitiva da controvérsia traz à tona a questão do controle político da ciência, assinala o autor. Afinal, quem deve decidir sobre seu desenvolvimento e aplicações?

O médico Oswaldo Cruz encontrou grande resistência a suas tentativas de pôr em prática medidas de profilaxia apoiadas no paradigma pasteuriano das doenças não só por parte da população em geral, como ficou patente no episódio da Revolta da Vacina, de 1904, mas também de seus próprios colegas de profissão. Poucos anos antes, enfrentara a desconfiança de médicos renomados no que dizia respeito ao uso e à aplicação de soros curativos. É essa a disputa que abordaremos a seguir, à luz dos conceitos aqui discutidos.

Inicialmente será feita breve caracterização dos primeiros anos da atuação de Oswaldo Cruz à frente da Diretoria de Saúde Pública da capital, indicando que a resistência que enfrentou estava fundada, em parte, em divergência acerca da eficácia dos métodos de controle das doenças derivados do conhecimento da bacteriologia. Em seguida, tratar-se-á especificamente da controvérsia sobre o uso do soro antipestoso - um dos produtos mais importantes do recém-criado Instituto de Manguinhos -, controvérsia que pode ser usada, com o devido cuidado, para compreender as dificuldades e o que estava em jogo naquele momento, no que concerne à consolidação da ciência médica brasileira.

\section{Oswaldo Cruz na Diretoria Geral de Saúde Pública e a controvérsia da sorologia}

A partir de 1850, a febre amarela consolidou-se como principal problema de saúde pública do Brasil, sobretudo por acometer preferencialmente estrangeiros - os imigrantes 
Jorge Augusto Carreta

eram os que mais sofriam, o que constituía grande ameaça ao plano das elites de substituir gradualmente a mão de obra escrava e empreender o embranquecimento do país, aproximando-o finalmente das nações europeias. ${ }^{5} \mathrm{~A}$ preocupação, entretanto, não se restringiu à febre amarela. A capital também era devastada por epidemias de cólera e varíola, além da tuberculose, doença já endêmica e associada às condições de vida e trabalho. Estas três últimas enfermidades, contudo, recebiam pouca atenção das autoridades naquele momento, pois acometiam a população negra e mais pobre (Chalhoub, 1996).

Oswaldo Cruz assumiu a Diretoria Geral da Saúde Pública (DGSP) em 1903. Como aponta Benchimol (1990, p.23), seu principal objetivo era eliminar as mais graves epidemias que grassavam no Rio de Janeiro desde meados do século XIX: febre amarela, varíola e peste bubônica. ${ }^{6}$ Com apenas trinta anos, mas detentor de invejável currículo, contava com a experiência de ter participado do bem-sucedido combate à peste bubônica na cidade paulista de Santos, em 1899. Era também o diretor do Instituto Soroterápico Federal (ou Instituto de Manguinhos), cujo processo de criação se desenvolveu entre 1899 e 1900.

Cukierman (2007, p.39) assinala que a ação de Cruz não se restringia a eliminar doenças e micróbios, mas realizar um saneamento que incluísse os aspectos técnico e social, ou seja, uma 'construção sociotécnica'. Isso correspondia a uma reforma completa cujo objetivo era, ao menos como projeto, realizar uma mudança que atingisse a nação em diferentes aspectos: físicos, no que tangia à higiene, mas também, intelectuais, morais, sociais e políticos. A grande aliada, nessa árdua tarefa, seria a ciência produzida nos países civilizados, sobretudo os da Europa do norte. Dessa parte do mundo vinha não só a ciência, mas também o modelo de civilização a seguir. ${ }^{7}$

Tão logo empossado no cargo, o novo diretor tomou medidas urgentes para combater a febre amarela. Conforme seu relato para o ministro do Interior, resolveu adotar o método profilático desenvolvido pelos americanos em Cuba (Cruz, 1904). Suspendeu todos os métodos higiênicos até então empregados e adotou a orientação definida no país caribenho, que consistia no combate ao mosquito e em isolar os amarelentos em suas residências, provendo os quartos dos doentes com telas de filó para impedir a entrada do transmissor. Medida de desinfecção complementar, já usada antes, era a queima de piretro e enxofre nas casas dos doentes, pelos quais pagava a autoridade sanitária.

Criou-se, dentro da Diretoria, um serviço específico para o combate da febre amarela, contando com um diretor técnico, cinco médicos auxiliares, administrador, almoxarife, escriturário, arquivista, chefes de turma, guardas de primeira e segunda classe, carpinteiros e serventes. A nova repartição era provida de razoável quantidade de tela metálica, filó, portas de tambor e substâncias inseticidas. Não foi dada trégua ao mosquito: "Todas as ruas da zona vigiada são percorridas constantemente, casa a casa, lavadas as caixas d'água, petrolizados os ralos e bueiros, retiradas as latas, cacos e recipientes passíveis de remoção e destruição, limpos os telhados e calhas; ainda assim fica de pé a luta contra as larvas contidas nas tinas e barris usados na lavagem de roupas, e que nesta cidade podem ser contadas por milhares" (Cruz, 1904).

Conforme José Murilo de Carvalho (1987, p.94), cerca de 2.500 mata-mosquitos designação pela qual ficaram conhecidos os funcionários de Cruz - espalharam-se pela cidade, dando preferência às áreas mais pobres e densamente povoadas. De 22 de abril a 31 
de dezembro de 1903, Oswaldo Cruz contabilizou 59 isolamentos, 2.692 expurgos completos de casas infeccionadas, destruição de 788 focos de larvas e 302 visitas de vigilância médica (Cruz, 1904). ${ }^{8}$ Soldados da polícia acompanhavam os funcionários da saúde, no caso de resistência de algum morador. Todo esse movimento aborreceu a vida dos habitantes dessas regiões, que eram obrigados a receber os mata-mosquitos, sair de casa para que as desinfecções fossem feitas e, no começo da operação, comprar as telas de filó para isolar eventuais doentes. Prejuízo maior tiveram os donos de estalagens e cortiços, muitos dos quais tiveram de ser reformados ou derrubados, por ordem da DGSP (Carvalho, 1987, p.95).

Não levou muito tempo para Oswaldo Cruz atrair a antipatia de parte da imprensa. Caricaturas e artigos de jornal expunham e ridicularizavam seus funcionários. Em outubro, O Jornal publicou artigo intitulado "As proezas de um mosquito", narrado em primeira pessoa pelo próprio Stegomyia. O mosquitinho relatava suas peripécias para escapar das juras de morte que lhe fizera o doutor Oswaldo Cruz. Dizia-se um "desgraçado pernilongo rajado, corrido de toda a parte, sem ter feito mal a ninguém, só porque em Havana disseram que eu carrego a febre amarela". Esperto, logo descobriu onde morar em segurança: "mosquito que estiver na casa de deputado, senador ou ministro está livre de perigo: é considerado como pernilongo de boa raça, incapaz de fazer mal a uma mosca". ${ }^{9}$

As disposições da DGSP eram tão rigorosas que, conforme a pena irônica de um dos cartunistas da Gazeta de Notícias - jornal que apoiava as ações de Oswaldo Cruz -, até as estátuas as temiam (Figura 1)

\section{CONTRA A myginney}

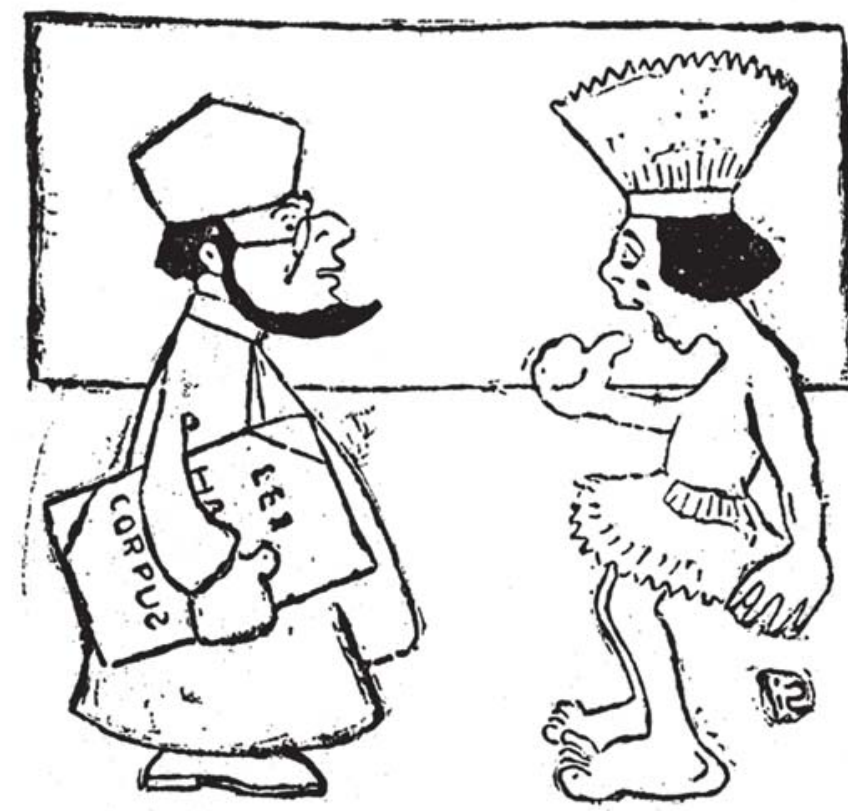

Figura 1: Charge publicada no jornal Gazeta de Notícias, do Rio de Janeiro, em 30 de julho de 1904 vai lavar.

- Sr. juiz, cu sou alli cla estatua, que o Prelcito

- E que deseja o amiguinho?

- Um Jixbcas-corfus, Sr. juiz, um haleass-corpus! 
Jorge Augusto Carreta

Multiplicavam-se, nos jornais, as denúncias de abusos cometidos pelos agentes da higiene. Em 20 de maio de 1904, o Correio da Manhã descrevia o entrevero ocorrido entre um oficial do Exército, morador na praia de Botafogo, e uma brigada de mata-mosquitos. Segundo o jornal, os funcionários invadiram atrevidamente a casa do militar, de balde, vassoura e creolina em mãos, para realizar a desinfecção. Sujos e malcheirosos, eles "sequer tiraram os chapéus", informava a notícia. Alguns dias depois, em 3 de junho, o mesmo jornal noticiava nova arbitrariedade. O doutor Serafim, comissário da Saúde Pública, ao realizar a desinfecção em uma casa da rua do Comércio, teria destruído móveis e roupas, além de sujar as paredes e portas do local. Os produtos usados ainda causaram incômodos à saúde dos moradores. Um deles chegou a ser preso, pois se trancou em sua casa e impediu a entrada dos funcionários da saúde. Alegava que desinfecção anterior afetara sua irmã e não consentiria que outra fosse feita. ${ }^{10}$

Em 30 de junho do mesmo ano, o Correio da Manhã recebia outra reclamação. O senhor Olegário José Monteiro, residente na rua Figueira de Mello, quase teve o domicílio arrombado por uma brigada desinfetadora. O morador não estava em casa e a brigada, após ameaçar invadir o local, acabou por deixar uma notificação que marcava a operação para o dia seguinte. Perguntava o periódico o que aconteceria se o morador estivesse em viagem longa. Seria multado? Teria a casa arrombada? E concluía: "Que fim levaram então as garantias prometidas na Constituição da República?".

De todos esses relatos, o caso mais grave foi o da morte da menina Iracema, em julho, causada por queimaduras de ácido fênico, um dos produtos usados nas desinfecções. ${ }^{11}$ Segundo o pai, José Ludovico dos Santos, a criança teria engatinhado sobre poças da substância, deixadas dentro da casa, na rua Major Ávila, pelos funcionários da saúde. Levado à discussão na Câmara pelo deputado Barbosa Lima, o caso ganhou os jornais e rendeu uma assustadora charge, na qual um funcionário da Saúde, encostado em tonel vazante e com seringa no feitio de lança ao ombro, assistia, com sorriso macabro nos lábios, uma pessoa sendo dissolvida numa poça de ácido fênico (Figura 2). O artigo, assinado por Gil Vidal, intitulava-se Applicação macabra (Vidal, 15 jul. 1904).

Além das denúncias dos supostos abusos cometidos pelas equipes da Diretoria, havia, mostra Cukierman (2007), a oposição de setores da classe médica à 'teoria havanesa'12, a exemplo de Nuno de Andrade (citado em Cukierman, 2007, p.122), antecessor de Cruz na Diretoria, que argumentava, em artigo publicado em 28 de junho de 1903 no Jornal do Commercio, que não se podiam abandonar completamente as práticas de expurgo e desinfecção, pois "enquanto não se demonstrar que no mundo exterior o germe da febre amarela não tem existência livre ... a fórmula profilática deve ser complexa, isto é, abranger em seus termos todos os processos de profilaxia em uso ...". Esse breve exemplo indica que a febre amarela ainda era controvérsia aberta, cujo fechamento demoraria alguns anos (p.125).

Não obstante a oposição que encontrou, a campanha de Oswaldo Cruz proporcionou resultados positivos, e o número de casos de febre amarela foi reduzido. Os mil óbitos de 1902 caíram para 548 no ano seguinte. Em 1904 foram apenas 48 mortes, 289 em 1905, 42 em 1906, 39 em 1907, quatro em 1908 e nenhuma no ano seguinte (Sant'Anna, 1978, p.56). Essas cifras certamente asseguraram a continuidade de sua política de combate às epidemias. 


\section{HYGIENE HOMICIDA}

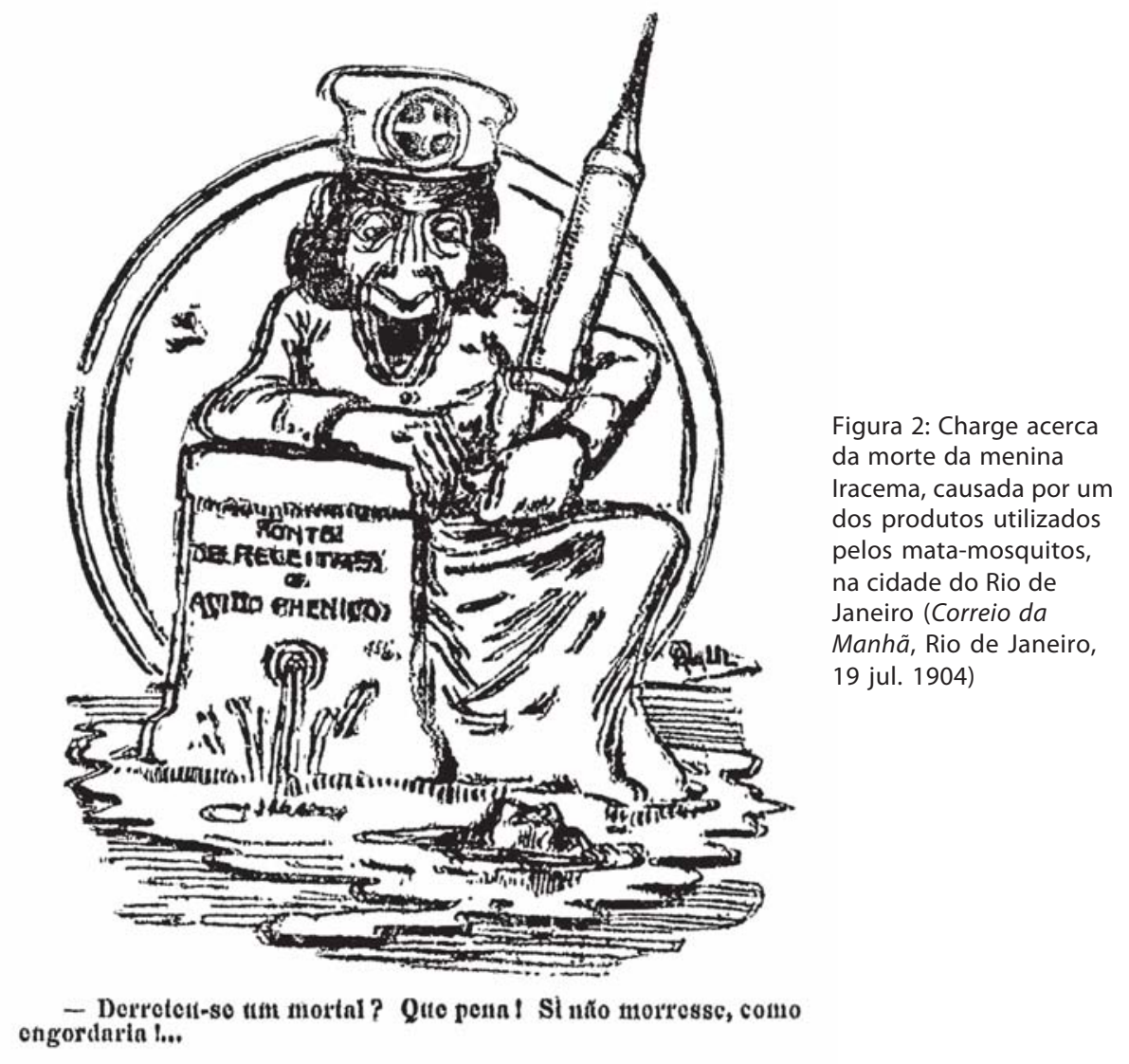

Cruz também enfrentou a peste bubônica combatendo os ratos portadores da doença. Instituiu um serviço de matança desses roedores e estabeleceu a cota mensal de 150 animais por empregado. Aqueles que excedessem esse número seriam premiados à razão de sessenta réis por cabeça. ${ }^{13}$ Como medida complementar, adotou o uso de gás Clayton em esgotos e câmaras de águas pluviais para asfixiar os bichos e, de quebra, matar mosquitos e larvas. Sabia, entretanto, que eliminar o vetor da peste não era suficiente; era preciso conjugar esse método com a vacinação, que, lamentava ele, tinha baixa adesão da população. Os 13 postos vacínicos que montou recebiam poucos interessados no profilático.

Apesar dos esforços e da produção de vacina e soro antipestoso pelo Instituto de Manguinhos, foram registrados, em 1903, 360 mortes por peste bubônica, um crescimento de aproximadamente 67\% em relação ao ano anterior (215 óbitos) (Cruz, 1906). ${ }^{14}$ Nos anos seguintes, a situação melhorou, embora a peste não tivesse desaparecido. Em 1907 a incidência da moléstia havia diminuído, mas ainda aquém das expectativas. ${ }^{15}$ Faltavam, de acordo com o diretor da Saúde Pública, algumas modificações no regulamento sanitário, que seriam apresentadas oportunamente. Outro problema dizia respeito aos modos de construir na cidade: muito se utilizava, por exemplo, o barro, facilmente escavável pelos ratos, que, assim, tinham acesso ao interior das moradias (Cruz, 1907). 
Jorge Augusto Carreta

Dificuldades semelhantes Oswaldo Cruz enfrentaria no combate à varíola, doença contra a qual a vacina era, em sua opinião, o melhor meio profilático, mas, assim como ocorria com relação ao soro antipestoso, não havia na população muitos que quisessem ser inoculados por ela. A reinstituição da obrigatoriedade da vacinação (e revacinação) foi mais um capítulo da conflituosa relação entre governo e camadas mais pobres da sociedade e levou, em 1904, ao famoso episódio da Revolta da Vacina. ${ }^{16}$ O estopim da sublevação foi a divulgação, pelos jornais, da proposta de regulamentação do projeto, feita por Oswaldo Cruz, que tornava a lei ainda mais severa. A imposição da vacina compulsória não seria apenas uma vitória contra a varíola; ela significaria uma imposição relativa à saúde para toda a sociedade ou, de outra forma, a imposição de determinados valores ou certa visão de mundo relacionados com aquilo que Roberto Machado e colaboradores (1978, p.50) denominaram medicalização da sociedade.

A vacina antivariólica chegou ao Brasil em 1804 e foi, de início, bem recebida. Em 1811, por ordem de dom João VI, foi criada a Junta da Instituição Vacínica, e a partir de 1830 a vacinação tornou-se obrigatória pelo menos para as crianças. A técnica de variolização teria sido aprendida em Lisboa, com o envio, por Felisberto Caldeira Brant, de algumas crianças escravas para teste (Chalhoub, 1996, p.107). O foco da vacinação voltou-se para os escravos, que recebiam o profilático logo que desembarcavam, e com isso se obteve a diminuição da incidência da varíola entre eles. Entretanto, com a extinção do tráfico a vacinação dos negros foi diminuindo gradativamente (p.110), e mesmo após a boa recepção inicial à prática da vacinação, o número de pessoas que se dispunham a recebê-la caiu consideravelmente, indicando uma possível resistência ao método. Já no final do século XIX, a população comparecia em pequeno número aos postos de vacinação, o que indica a pouca difusão dessa prática. ${ }^{17}$ Nos meses anteriores à revolta travou-se, nos jornais de grande circulação, um apaixonado debate sobre a vacina, desvelando posições a ela contrárias e favoráveis. Casos de supostas mortes causadas pela vacinação apareciam eventualmente. ${ }^{18}$

Parece ter havido uma desconfiança, derivada do medo de que a vacina antivariólica ou o soro antipestoso pudessem disseminar doenças. Esse medo não se restringia ao desinformado 'zé-povinho'; a classe médica também não tinha certeza absoluta sobre os efeitos desses preparados. Em carta dirigida a Oswaldo Cruz, o doutor Miguel Pereira, conhecido médico carioca e membro da Academia Nacional de Medicina, manifestava suas dúvidas quanto ao emprego do soro antipestoso. Declarava-se inimigo de seu uso, que desaconselhava a seus familiares. Na carta esclarecia não se tratar de questão pessoal, mas sim científica:

Sei, pelo que tenho lido, que a aplicação de soro tem reações normais e agora sei, pelo que observei em dez imunizados, que estas reações nem sempre são convenientes e que desses muitos, os falecimentos são de insólita gravidade. Nestas condições particularizando as medidas profiláticas ao caso de morte do meu pranteado Mestre [o professor Francisco de Castro] cujo mal, a despeito da rudimentar higiene que se lhe apôs, não estendeu o seu raio de disseminação, eu cheguei a temer mais do soro, qualquer que ele seja, venha de onde vier, preparado por este ou por aquele, do que da própria peste e, de conformidade com este meu modo de pensar, tenho sempre agido com a maior franqueza certo de que nesta opinião ninguém acharia sentido de hostilizar um amigo, que prezo no mais alto 
ponto, nem encontraria elementos para urdir a intriga que por aí anda desenfreada (Pereira, 7 nov. 1901).

Oswaldo Cruz (21 nov. 1901) respondeu-lhe em tom polido, mas decepcionado. Considerava o desprezo pela soroterapia um verdadeiro "crime de lesa-ciência". E ponderava, minimizando os efeitos adversos do uso do soro: "O que são os relativamente insignificantes acidentes devidos à inseparável ação tóxica dos hemossoros terapêuticos em relação à garantia absoluta e incontestável conferidas pelas injeções preventivas do soro quer seja ele antipestoso, antidiftérico ou antitetânico?". E terminava por afirmar que o colega podia até "condená-lo" pessoalmente, desde que "absolvesse" o soro. A ironia da sugestão magoou Miguel Pereira, que tratou de esclarecer que não desprezava a soroterapia, mas se referia ao caso específico da doença de seu mestre, para o qual não acreditava que o soro pudesse ser útil. Nutria o maior respeito por Manguinhos e seus cientistas e se comprometia a mandar o relato de suas observações sobre o uso do soro (mencionadas na primeira carta), para que Cruz pudesse aproveitá-las de alguma forma. A polêmica encerrou-se com missiva deste último desculpando-se pelo mal-entendido e agradecendo o envio das observações sobre os acidentes com soro.

Apesar de Cruz atenuar a importância dos acidentes com o soro, eles assombravam os cientistas. Preocupado com isso, ele manteve contato com pesquisadores do Instituto Pasteur de Paris, como Alexandre Besredka (1870-1940). ${ }^{19} \mathrm{Na}$ correspondência entre ambos, revela-se a dúvida sobre qual seria o melhor método para a produção do soro antipestoso. Para o cientista russo, seria aquele obtido de culturas vivas dos micróbios, mas alertava: "a questão das toxinas da peste ainda está sob estudo e até agora ela não passou do setor das pesquisas de laboratório, é bom dizer que até agora não se faz uso em sentido prático". E recomendava cautela a Cruz: "Se tenho um conselho a dar-lhe é o de praticar as injeções intravenosas com muito cuidado, empurrar o êmbolo tão lentamente quanto possível e nunca usar emulsões pouco espessas. Infelizmente, apesar de tudo, temos frequentemente que lamentar acidentes, às vezes mortais, consecutivamente às injeções dos cultivos empestados [em cavalos] ... ao que são eles devidos? Será a embolias, ou a outra coisa. Não se sabe" (Besredka, 30 dez. 1899).

Cruz também consultava outros cientistas brasileiros sobre questões da sorologia. Desde 1899 correspondia-se com Vital Brazil, diretor do Instituto Butantan, com quem trocava experiências e verificava os mútuos experimentos. ${ }^{20} \mathrm{Um}$ dos grandes problemas em pauta era determinar a dose correta do soro ou vacina, que provocava em geral alguma reação tóxica. O erro na dosagem poderia matar quem recebia o produto, além de existir o risco de contaminação por outros microrganismos. Também não se sabia qual o melhor método de administração, se por injeção subcutânea ou intravenosa. Brazil usou inicialmente a técnica de produção a partir de culturas mortas, e experimentou o soro produzido de acordo com o método do italiano Terni, do Instituto de Messina, mas o teste com cobaias mostrou-se inócuo. Externou então seu ceticismo a Oswaldo Cruz:

Quanto ao soro [do Instituto] de Messina ou do professor [Camilo] Terni são bem desfavoráveis as informações que posso fornecer. É um soro muito mal acondicionado em vidros ordinários, arrolhados com cortiça. Não é asséptico; encontramos o b. [bacilo] mesentérico [causador da tuberculose mesentérica] em uma vacina. Instituímos uma série 
Jorge Augusto Carreta

de experiências para ajuizar do valor profilático do termo. Tomamos duas cobaias e dois ratos brancos; injetamos em cada um $1 / 2 \mathrm{cc}^{3}$ de soro. Três horas depois da injeção do soro inoculamos cultura da peste na cobaia no 1 , e o mesmo fizemos em outra cobaia testemunha; 24 horas depois inoculamos a segunda cobaia que havia recebido soro e outra testemunha; 48 horas depois fizemos o mesmo ao primeiro rato; 72 horas depois fizemos o mesmo ao rato $n-2$. Todos estes animais sucumbiram com as testemunhas. O soro Terni parece, pois, muito pouco ativo, para não dizermos que não tem valor algum. Vamos tentar uma nova série de experiências aumentando a dose de soro. Estou estudando a vacina de Haffkine, modificada pelo Terni. Também não é asséptica. Tem o mesentérico em tão grande quantidade, que encontrava-se o mesmo por preparações diretas (Brazil, 9 dez. 1899).

Em carta enviada alguns meses depois, Brazil (5 jun. 1900) avisava a Cruz que, de todas as cobaias inoculadas com a vacina antipestosa de Haffikine modificada por Terni, nenhuma sobreviveu, apesar das diferentes dosagens aplicadas. ${ }^{21}$ Alguns dias depois, Cruz (14 jun. 1900) respondeu à carta de Brazil:

Felicito-te ardentemente pelo método e critério com que empreendeste as experiências cujo resumo tiveste a requintada gentileza de enviar-me. Esses teus resultados são de grande alcance e concorrem para a formação de uma base sólida para o julgamento dos processos do professor italiano. Assim que nosso Instituto estiver preparado procurarei verificar teus resultados com a vacina aqui preparada e elucidar também vários pontos que me deixam em dúvida. $1^{\circ}$ ) Verificar se há uma maior receptividade dos animais para a peste no período que precede o aparecimento da imunidade conferida pelas vacina antipestosas (Haffkine e Terni); $2^{\circ}$ ) nesses estudos do prof. Terni referentes à peste e entre eles sobretudo, a questão da possibilidade da passagem de certo micróbio como a bactéria da tuberculose (colônias tuberculosas) no exsudato peritoneal, que é matéria-prima para a preparação da vacina. E no caso positivo verificar se a técnica de preparo e a esterilização empregada são suficientes para matar a bactéria de Koch por acaso existente. ${ }^{22}$

As vacinas e soros eram feitos com grande dose de imprecisão e podiam conter, se não fossem adequadamente manipulados, outros micróbios causadores de doenças. Conforme se depreende das cartas, era grande o risco de usar esses produtos em seres humanos. Oswaldo Cruz optara pelo método de produção de soro a partir de culturas vivas, o que lhe parecia trazer melhores resultados do que aqueles conseguidos pelo colega paulista:

Aqui continuamos a trabalhar no preparo da vacina (em cuja técnica introduzimos algumas modificações, que te comunicarei se assim o quiseres) e no soro. Já injetamos culturas vivas em alguns cavalos e tivemos a satisfação de verificar nesses animais que o bac. [bacilo] da peste desaparece do sangue antes de decorridas 24 horas. Estamos agora procurando determinar o momento exato do desaparecimento do micróbio da circulação periférica. Como acidente tivemos umas artrites febris acompanhadas de grande desnutrição. Temos continuado a imunização, fazendo alternadamente inoculação de culturas vivas e mortas (Cruz, dez. 1900).

Brazil seguiu as orientações do colega do instituto carioca e passou a utilizar as culturas vivas (ou virulentas) no processo de produção de soro. Seus resultados foram bastante animadores: "Já comecei a fazer inoculações virulentas. Estamos na quarta. Tenho o prazer de confirmar as tuas observações: o b. Yersin desaparece mui rapidamente do sangue do animal imunizado anteriormente com culturas mortas" (Brazil, 28 mar. 1901). 
Provavelmente animado com o sucesso de suas experiências e a confirmação delas por Brazil, o cientista de Manguinhos anunciava ao colega paulista, em fevereiro de 1901, que entregara o primeiro lote de soro antipestoso. E relatava o método pelo qual o obtivera:

\begin{abstract}
Como te disse anteriormente, comecei a inocular os cavalos com culturas vivas em doses progressivamente crescentes e repetidas desde que os animais não apresentavam mais vestígios de reação (oito dias). Indo paulatinamente inoculei até a quantidade de cultura desenvolvida em 48 horas numa garrafa de ágar. Tendo chegado a esse ponto, no fim de seis meses sangrei o primeiro animal no 15이a após a última injeção [e] obtivemos um soro com o qual conseguimos preservar cobaias com a dose de 0,2 cc contra a inoculação de 0,4cc de cultura em caldo duma raça do bacilo da peste atenuado capaz de matar uma cobaia de $300 \mathrm{~g}$ no fim de 17 a 19 dias. À vista desse resultado e seguindo os conselhos de Yersin, que fornece soro antipestoso no fim de três meses de imunização com culturas vivas, julguei poder entregar a primeira porção de soro. Estamos procedendo a estudos mais aprofundados a fim de verificar a ação preventiva e curativa para o micróbio no mais alto grau de virulência. Brevemente pretendemos enviar-te, como lembrança, uma amostra de nosso soro, o que não fazemos agora por não dispormos de um só vidro (Cruz, 27 fev. 1901). ${ }^{23}$
\end{abstract}

Em 1902, Cruz publicou um livro intitulado Dos acidentes em soroterapia. Nele, procurava defender de seus detratores a prática da soroterapia. Ressaltava que também na Europa houvera reações violentas contra a soroterapia, mas que com o tempo a técnica fora apurada e os poucos casos de intoxicação por soro praticamente desapareceram. Fornecia dados estatísticos do uso do soro de Manguinhos, assim classificando os acidentes: benignos, aqueles caracterizados por pequenos incômodos ao paciente, que entretanto não o impediam de levar vida normal; e graves, que prendiam a pessoa ao leito por tempo mais ou menos longo. Acrescentava que, de 123 casos observados, 58 apresentaram algum tipo de reação, benigna ou grave, não sendo registrada nenhuma morte.

Apesar da defesa desses métodos, a correspondência trocada entre eminentes bacteriologistas do período confirma, porém, que a soroterapia ainda era marcada por boa dose de incerteza, o que justificaria as suspeitas de médicos como Miguel Pereira. Os médicos cientistas Francisco Fajardo e Eduardo Chapot Prévost comparavam suas experiências com as de Cruz e relatavam as reações aos diferentes tipos de soros. Em 8 dezembro de 1901, Fajardo relatava ao diretor de Manguinhos que, de quarenta pessoas inoculadas com soro, quatro (10\%) apresentaram reações dignas de serem consideradas acidentes.

Chapot Prévost enviou a Fajardo o resultado de suas inoculações com o soro e a vacina de Haffkine. Receberam os preparados 28 homens (18, soro; dez, vacina Haffkine), 28 mulheres (20, soro; oito, vacina Haffkine) e sete crianças (cinco, soro; duas, vacina Haffkine). Segue o que foi apurado por Prevost:

Os acidentes observados foram uns locais outros gerais. Os primeiros manifestavam-se do terceiro dia em diante. Às vezes, prolongavam-se e eram agravados por acidentes, ora limitados aos membros inferiores ora generalizados, prolongando-se os fenômenos por alguns dias. Entre os homens, três que não foram vacinados com a vacina Haffkine apresentaram fenômenos muito graves. Um deles, três dias depois de inoculado com o soro, foi acometido de calafrio, febre de $39,5^{\circ}$ e depois de $40^{\circ}$; dores fortes nos gânglios 
Jorge Augusto Carreta

inferiores de ambos os lados e escarros a princípio menores, depois sanguíneos. A injeção de maior dose de soro, em vez de atenuar ao fenômeno, agravou-o, de modo que só com doses fortes de [ilegível] é que os fenômenos foram cedendo pouco a pouco, tendo-se prolongado por dez dias. Outro ..., só oito dias depois de inoculado com o soro [é] que teve intensíssima dor ciática, principalmente no membro inferior direito, ficando prostrado no leito durante 15 dias. O ..., que também [foi] inoculado com o soro, teve, alguns dias depois de inoculado, fenômenos que fizeram suspeitar a peste pelo dr. Portella, pois, além da febre elevada, que não cedia à medicação alguma teve fenômenos pulmonares e adenites por alguns dias. Três senhoras inoculadas e vacinadas apresentaram, três dias depois de inoculadas, artrologia fortíssima, internada em várias articulações e acompanhadas de febre intensa, prolongando-se os fenômenos por uns oito a dez dias em cada uma delas .... Em uma delas as dores localizam-se muito tempo nas articulações maxilares. A não serem estes casos febris e mais assustadores, manifestaram-se em geral ... mais leves [casos de] erupções escarlatiniformes, eritemas, ora limitadas à região inoculada, ora a zonas mais ou menos afastadas. As articulações mais comumente comprometidas foram as do joelho, do cotovelo e da espádua ... Em suma, de todas as pessoas por mim inoculadas não houve uma só que não apresentasse algum problema podendo ser atribuído ao trabalho de imunização (Prévost, 11 fev. 1902; grifos meus).

Entre os homens, 25 apresentaram alguma reação, sendo três graves. Das mulheres foram oito casos, nenhum grave. Todas as crianças (sete) apresentaram vermelhidão ou erupções na pele após receber o soro ou a vacina. Fajardo encaminhou os resultados a Oswaldo Cruz, que estava preocupado em coligir dados sobre os experimentos com soro. ${ }^{24}$ Em seu livro sobre os acidentes soroterápicos, ele concluiu:

Se compararmos agora as vantagens obtidas com as injeções preventivas do soro antipestoso, com os acidentes que têm produzido, vemos que estes devem ser completamente esquecidos, à vista das reais vantagens até hoje colhidas. Ninguém se lembrou ainda de eliminar da terapêutica medicamentos como a antipirina, o ópio, o iodeto de potássio, o mercúrio, a atropina e tantos outros, porque tenham produzido acidentes, mesmo mortais, o que nunca aconteceu com o soro (Cruz, 1902, p.22).

Ele não contava, porém, que um de seus mais próximos colaboradores viesse a falecer alguns anos depois justamente em decorrência de um acidente soroterápico. Francisco Fajardo morreu em 6 de novembro de 1906, aos 42 anos, após se autoinocular com o soro antipestoso de Manguinhos. Um choque anafilático (reação imunológica ao soro) o teria matado. O Jornal do Commercio de 7 de novembro de 1906 descreveu a morte de Fajardo em seu consultório na rua do Hospício. Durante a manhã, ele recebeu seus clientes normalmente. A certa altura, pediu licença à esposa do jornalista Joaquim de Lacerda, a quem atendia, para se vacinar: "Tenha a paciência de esperar um pouco, porque preciso vacinar-me agora. Tenho um doente suspeito de peste e convém acautelar-me". Dito isso, convidou Lacerda para assistir à inoculação. Enquanto se preparava, o médico contou ao jornalista que desde o dia anterior tinha uma irritação intestinal. Lacerda obtemperou que a vacina talvez não fosse indicada naquela situação. Fajardo disse que já estava acostumado com os efeitos da aplicação, que no dia seguinte sempre lhe dava dores no corpo e mal-estar geral.

O médico misturou na seringa a vacina e o soro antipestosos e a aplicou na região abdominal. Pouco passava das três horas da tarde quando se vestiu e voltou à sala de consulta, para continuar o atendimento. Alguns minutos depois, a esposa do jornalista 
observou, assustada, a extrema palidez de Fajardo. Lacerda também se alarmou e disse ao médico que suas orelhas estavam muito vermelhas, os olhos, injetados e que seu rosto apresentava manchas rubras. Com falta de ar, o médico andou até a sala em que pouco antes tomara a vacina e o soro e deitou-se na cama. Esfregava a região do coração e, reclamando de dificuldade em respirar, pediu o aparelho de respiração artificial. O doutor Carlos Seidl, que estava no consultório, veio em socorro do colega. Pouco depois, Fajardo perdeu os sentidos. Vários médicos acorreram à clínica, entre eles Rocha Faria, Miguel Couto, Chapot Prévost, Azevedo Sodré, Vieira Souto, Oswaldo Cruz e Fernando Magalhães. Durante o resto dia, autoridades como o barão do Rio Branco e o general Quintino Bocaiúva também passaram pelo local em que Fajardo agonizava - o que atestava seu prestígio. Apesar de toda a assistência, ele faleceu pouco depois das 11 horas da noite. Sua morte foi lamentada na Câmara e no Senado, e o presidente da República mandou representante ao enterro.

Não havia certeza sobre a causa da morte. A edição de 7 de novembro de 1906 do jornal Gazeta de Notícias relatou que as opiniões médicas eram contraditórias em mais de um aspecto, "permanecendo todas elas no amplo das conjecturas e hipóteses". Para alguns, fora um caso de peste; para outros, uma grave intoxicação urêmica (intoxicação por substâncias presentes no organismo e que o paciente não consegue eliminar pela urina) seria a responsável. Havia ainda a possibilidade de intoxicação pela vacina, causada por descuido na aplicação e, neste caso, um choque peritoneal teria vitimado o médico. A suspeita maior recaía sobre o soro fabricado em Manguinhos.

Contudo, a Gazeta ponderou, após consultar "alta personalidade científica, competentíssima na matéria" (talvez Oswaldo Cruz ou um de seus colegas), que os acidentes com soro podiam ser atribuídos a duas ordens de fatos: a má preparação do soro ou a natureza própria desses líquidos. A primeira conjectura era descartada logo de saída pelo jornal, pois os profiláticos de Manguinhos seriam manipulados com o máximo cuidado e atenderiam aos preceitos mais rigorosos de qualidade. Assim, a morte poderia ser consignada às habituais reações observadas após as vacinas.

A morte acidental de Fajardo fez emergirem as divergências internas entre os cientistas de Manguinhos, como demonstra carta de Oswaldo Cruz a Henrique da Rocha Lima, que se achava na Alemanha estudando bacteriologia no Instituto de Higiene de Berlim:

Ultimamente, com a morte de Fajardo, que ocorreu, por caiporismo nosso, após uma sessão de soro-vacinação, as coisas chegaram a um extremo cujas consequências a muito custo consegui evitar. Imagina que o [Henrique Beaupierre] Aragão em discussão com o [Figueiredo de] Vasconcellos disse que a técnica de Vasconcellos era tão rigorosa que preparava o soro que matou o Fajardo!! Imagine você o perigo que corre a nossa solidariedade, que constituía nossa maior força e felicidade!! (Cruz, 21 nov. 1906).

Oswaldo Cruz relatava o clima tenso que se instalara, no Instituto, entre Vasconcellos, Aragão e Arthur Neiva, após a morte de Fajardo: "Infelizmente no Instituto as coisas não vão a bom sabor, o que me tem trazido as maiores contrariedades íntimas e o maior desalento possível: o Aragão ... tem ultimamente afetado uma hipertrofia ... do 'eu' e com uma ilimitada confiança nos próprios conhecimentos e mais absoluto desprezo pelo que fazem os outros companheiros de trabalho, tem-lhes tornado a vida, anteriormente tão 
Jorge Augusto Carreta

feliz, em um verdadeiro martírio" (Cruz, 21 nov. 1906). Em outra carta a Rocha Lima, comentava as repercussões da morte de Fajardo, que segundo ele, foram suportáveis e preservaram Manguinhos. Os ataques mais duros foram dirigidos a ele próprio por 'desafetos' como Benjamin da Rocha Faria, seu ex-professor e titular da cadeira de Higiene da Faculdade de Medicina:

O Rocha Faria, que prestara socorros ao Fajardo, doutrinando, como é seu hábito, exclamou: "Veja mais esta beleza de seu Oswaldo, que anda querendo iludir a todos nós!" ... A maledicência vem logo arquitetando perversidades sobre a morte de Fajardo ... . Ainda hoje, fervilham as mais desencontradas versões e esqueceram-se completamente de nós. ... De que morreu o Fajardo? Não sei. De nefrite? ... De choque peritoneal? Falava-se em anafilaxia. Quero apurar isto, mas ainda não ousei abordar o [Miguel] Couto, que deu como causa mortis: toxemia, sideração [aniquilação] dos centros bulbares (Cruz, 31 dez. 1906). ${ }^{25}$

Pouco tempo depois, Cruz convenceu-se de que a morte de Fajardo nada teve a ver com a inoculação do soro e sim a uma condição prévia do falecido. Em fevereiro de 1907 ele dizia a Émile Marchoux, do Instituto Pasteur de Paris, que estivera no Brasil em 1901 para estudar a febre amarela:

O caso de Fajardo consternou a todos nós. Não creio que se tenha tratado dum caso de anafilaxia, porquanto havia anos que ele não se tinha inoculado com soro. Sei bem disto, porquanto todo o soro é como sabe, fornecido por nós. Outra coisa qualquer motivou a morte de nosso pranteado colega, que ultimamente estava extremamente abatido e adoentado. Não creio muito na existência aqui de casos de anafilaxia no homem. Em nosso Instituto todos nós temo-nos injetado a curto prazo sem acidentes (Cruz, 15 jan. 1907).

O acidente que levou Fajardo à morte talvez tenha sido apenas um caso isolado, e não permite afirmar com segurança que foi causado pelo soro de Manguinhos. O erro pode ter sido de Fajardo na manipulação ou na dosagem, o que, no entanto, é difícil de acreditar, já que o médico acumulava a experiência de alguns anos nos testes soroterápicos. De qualquer modo, evidencia-se uma não desprezível parcela de incerteza nesse começo da soroterapia no país. O fato deve ter contribuído para fortalecer a ideia de que os soros e os estabelecimentos que os produziam não eram seguros.

Por que Oswaldo Cruz era tão enfático em afirmar a segurança do uso de soros e vacinas, se pairava uma incerteza sobre a segurança desses produtos fornecidos por seus colaboradores do exterior e do Brasil? Por certo, além da crença na validade das técnicas de produção de soros e vacinas, era preciso preservar o projeto de Manguinhos e seus planos para a saúde pública. Cruz devia acreditar que era uma questão de tempo até que os soros estivessem totalmente aperfeiçoados e que pequenos acidentes eram toleráveis em nome de um bem maior, a erradicação das moléstias epidêmicas. ${ }^{26}$ Porém ele não conseguiu vencer completamente a desconfiança sobre as vacinas e os soros produzidos por Manguinhos um temor já se manifestara claramente na discussão sobre a vacina obrigatória, ocorrida dois anos antes da morte de Fajardo. 


\section{Considerações finais}

O exame das controvérsias desvela estratégias adotadas no debate e interesses não explícitos na defesa de certos meios profiláticos. O estudo da febre amarela, por exemplo, revela-nos que o interesse em erradicar essa doença estava relacionado a objetivos sociais mais amplos, entre eles a substituição da mão de obra escrava pela imigrante e o 'branqueamento' do país. Um 'mal xenófobo', a febre amarela acometia estrangeiros e preservava negros e mestiços. A tuberculose, que ocorria principalmente nestes últimos grupos sociais, era combatida com menos ênfase pelas autoridades, ainda que não estivesse fora de sua agenda. Um exemplo dessa associação entre medicina e técnicas de controle social pode ser encontrado em João Batista de Lacerda, médico que se dedicou à descoberta e ao combate ao germe da febre amarela em finais do século XIX. Ao preconizar métodos de prevenção contra a disseminação da doença, alinhava-se ao ideário que fazia da população pobre, amontoada nos cortiços e casas de cômodos no Centro da cidade, o principal alvo da intervenção oficial (Benchimol, 1992).

Quanto às estratégias adotadas pelos contendores, procurei mostrar que o sucesso de uma argumentação depende da forma como são interpretados os dados dos experimentos científicos. Como assinala Del Sesto (1983), ainda que usando os mesmos métodos, partes diferentes interpretam diferenciadamente o resultado das experiências. Quando algum cientista não confirmava a observação de um colega, este tratava imediatamente de acusálo de imperícia ou desconhecimento dos 'verdadeiros' métodos da ciência experimental. Diante da dificuldade de convencer os pares, muitos recorriam à retórica para sustentar suas descobertas. Assim, mesmo sem poder atestar a segurança dos soros, Oswaldo Cruz empenhava-se em desacreditar seus adversários acusando-os de pouca intimidade com a medicina experimental.

Nas controvérsias quanto ao uso de soros ou vacinas é possível identificar a presença de fatores extracientíficos ou, como os chamou McMullin (1987), não epistêmicos. No debate público observa-se o que Nelkin (1987) denominou medo do risco, isto é, o temor de que esses medicamentos, cujos mecanismos de funcionamento não estavam bem elucidados, representassem um perigo à saúde coletiva. Outra dimensão não cognitiva, visível no debate, era a da liberdade individual, à qual a vacinação poderia representar uma ameaça.

A correspondência trocada no começo do século XX por Oswaldo Cruz, Eduardo Chapot Prévost e Francisco Fajardo sugere que a dificuldade de produzir um soro antipestoso seguro geraria forte desconfiança acerca de todos os outros produtos biológicos do Instituto de Manguinhos. A morte de Fajardo, em 1906, reforçou essa desconfiança, ainda que pudesse ser considerada apenas um caso isolado.

É de supor que Cruz não agiu de má-fé e que de fato acreditava na eficácia da sorologia, mas havia outros fatores em jogo. O caso da sorologia brasileira se aproxima de um estudo recente conduzido por Brian Martin (2001a), acerca da controvérsia sobre o surgimento da síndrome da imunodeficiência adquirida (Aids). ${ }^{27}$ De acordo com o autor, duas teorias sobre o surgimento dessa doença se enfrentaram na década de 1990. A primeira, que fazia parte do mainstream científico, acreditava na teoria da transferência natural (cut hunter theory), segundo a qual o vírus teria passado à espécie humana pelo contato entre caçadores 
Jorge Augusto Carreta

e macacos portadores o vírus da imunodeficiência símia (SIV, na sigla em inglês). A suspeita é de que a doença tenha surgido na África Central, onde macacos eram caçados ou mantidos como animais de estimação, facilitando assim o contato dos homens com o SIV. A teoria concorrente associava a disseminação da Aids ao uso dos rins desses animais em culturas que serviriam de base para a vacina oral contra a poliomielite, largamente adotada no continente africano. Assim, o contato do vírus SIV com humanos não teria ocorrido por via natural, mas sim por meio de um produto biológico criado pelo homem. Essa teoria ficou conhecida como oral polio vaccine (OPV).

Martin, que se envolveu pessoalmente nessa controvérsia, relata que, apesar de não haver evidência conclusiva que confirmasse a transmissão natural e refutasse a teoria OPV, esta foi marginalizada e só discutida seriamente após ganhar a grande imprensa, por meio de um artigo publicado na revista musical americana Rolling Stone. Posteriormente, a publicação do livro The river, do jornalista e escritor Edward Hooper, fez com que a comunidade científica levasse a sério a teoria da transmissão do HIV pela vacina oral contra a pólio. Em 2000 a Royal Society, prestigiosa associação científica inglesa, organizou um encontro para debater essas teorias e houve claro favorecimento da teoria da transferência natural. Um dos motivos que explicam essa marginalização, que faz parte daquilo que Brian chama de dimensão política da ciência, está relacionado com a ameaça que a teoria OPV representaria para a imagem da pesquisa médica e para os programas de vacinação contra outras doenças. A representação social da medicina como 'salvadora de vidas' ficaria seriamente abalada, e colocaria em xeque outros ramos da investigação médica, como o transplante de células, tecidos ou órgãos de animais em humanos (xenotransplantation), a vacina para a Aids e a engenharia genética. ${ }^{28}$

No caso brasileiro em questão, vimos que Oswaldo Cruz travava árdua luta para conseguir fazer valerem seus projetos para a saúde pública e para construir o Instituto de Manguinhos, fundado em finais de 1899. Admitir a possível falibilidade da sorologia poderia colocar em risco todo o seu empreendimento e o projeto de pesquisa daquele instituto. Desse modo, tanto no caso da sorologia quanto da vacina contra a varíola, a estratégia do diretor da Saúde Pública era rejeitar veementemente todos os ataques e afirmar a segurança dos produtos que seus laboratórios fabricavam. Usando os termos de Bruno Latour (1988), Cukierman (2007, p.57-58) aborda o processo de tradução presente no discurso dos médicos daquele período, que evidenciava, para os governantes, incapazes de dominar a linguagem da microbiologia, a necessidade de um instituto soroterápico, sem o qual a população brasileira estaria entregue à sanha das doenças epidêmicas. ${ }^{29}$

Cukierman (2007), ao tratar da viagem de Oswaldo Cruz a Santos em outubro de 1899 para investigar uma possível epidemia de peste bubônica, indica como o médico, em seu relatório feito às autoridades, explicou vagamente a morte de um jovem em decorrência da doença (àquela altura praticamente comprovada), apesar de ter recebido doses do soro antipestoso:

Por que faleceu o rapaz se aplicaram-lhe diariamente doses de soro antipestoso? A resposta de Oswaldo é fundamental para entender o que iria sobrevir na guerra brasileira ao bacilo da peste: "as injeções de soro foram sempre feitas em quantidade insuficiente, porque havia grande falta desse meio terapêutico" ... De olho no futuro da peste mas 
também no futuro do laboratório para fabricar seu antídoto, Oswaldo procura deixar claro, ainda que en passant, apenas o aspecto que diz respeito à falta do precioso recurso terapêutico. Embora não diretamente explicitado, se a moléstia reinante em Santos for a peste, terá o Brasil que se confrontar com aquela falta e se 'virar' com um soro nacional. Não há tempo a perder porque com a peste não se brinca, muito menos com a oportunidade de fundar um instituto soroterápico (p.49).

A alusão de Cruz à falta de soro importado, ainda que fugaz, era obviamente mais um argumento a amparar aqueles que defendiam a necessidade de fundação de um instituto nacional de produção de soros e vacinas. ${ }^{30} \mathrm{O}$ que aqui interessa, entretanto, é o que não é explicado: por que o soro não funcionou, apesar das injeções diárias? Seria devido à quantidade insuficiente ou a uma possível inocuidade? ${ }^{31}$ Os erros e possíveis 'desastres' não invalidam o uso dos soros, mas revelam aquilo que John Law (1989, citado em Cukierman, 2007, p.51-52) chamou de precariedade do processo de construção de uma ordem a partir de elementos heterogêneos. Pondera Cukierman (p.106) que o processo é tumultuoso e falível, características que não podem ser mostradas em público sob pena de ter desacreditados a ciência e o poder dos médicos. E isso não só no âmbito nacional, mas também no internacional, pois Oswaldo Cruz buscava a legitimação do Instituto de Manguinhos perante a Nova Metrópole, a Europa do norte.

Não encontrei estatísticas detalhadas sobre acidentes sorológicos além daquelas produzidas por Cruz e seus colaboradores, mas mesmo esses poucos dados indicam que as vacinas e os soros ainda não eram suficientemente seguros. Os depoimentos de outros médicos na imprensa e os relatos dos acidentes causados pelo uso de soros ou pela vacinação, descontados possíveis exageros, apontam na mesma direção. Suponho ainda que essa desconfiança, seja dos médicos ou da população, não apenas se devia à possível falibilidade dos soros e vacinas, mas também refletia os métodos de combate às doenças empregados por Oswaldo Cruz na sua atuação à frente da DGSP.

Naquele momento, uma das batalhas fundamentais a ser vencida pelos médicos, na afirmação de sua ciência, era a da microbiologia. Até os médicos partidários da teoria microbiana reconheciam que a ausência de um consenso mínimo nessa área impedia o reconhecimento pleno da medicina por parte da população e do poder público. Por mais que Oswaldo Cruz se tenha esforçado para se desvincular da tradição da pesquisa biomédica anterior a Manguinhos, algumas controvérsias do século anterior permaneciam, ainda que residualmente, tal como a que se referia à associação entre doença e micróbios.

Como bem mostraram Stepan (1976) e Cortes (1993), o aspecto realmente inovador desse instituto foi o estabelecimento de um padrão de organização da pesquisa no país (o que não implica dizer que antes de sua fundação não houvesse ciência no Brasil). Em Manguinhos, havia a preocupação - quase ausente nas instituições anteriores - com a formação de cientistas e com a associação entre ensino e pesquisa, que Cruz reputava indispensáveis para o sucesso de sua empreitada. ${ }^{32}$ É possível perceber, na própria fala do cientista e na relação que mantinha com a Faculdade de Medicina e alguns de seus professores, que ele procurava se distanciar de uma tradição de pesquisas que considerava infrutífera. ${ }^{33}$ Seu sucesso em vida e a consolidação de seu mito não se devem apenas a sua inegável capacidade como cientista, mas sobretudo a sua habilidade como operador desses 
Jorge Augusto Carreta

aspectos políticos e simbólicos da ciência. Ou seja, tão importante quanto o trabalho no laboratório era o trabalho fora dele, a lida com uma variedade de atores com interesses diferentes e que deveriam ser convencidos e alinhados em rede, de modo a permitir a consolidação do conhecimento científico e dos espaços para seu desenvolvimento. Como sugere Cukierman (2007, p.150), pode-se dizer que a genialidade de Oswaldo Cruz vinha de seu "dom da ubiquidade humanizado", quer dizer, sua presença em diferentes espaços, tratando com diferentes interlocutores.

\section{NOTAS}

* Este artigo condensa discussões desenvolvidas em "O micróbio é o inimigo": debates sobre a microbiologia no Brasil (1885-1904), tese de doutorado que defendi em 2006 junto ao Programa de Pós-graduação em Política Científica e Tecnológica do Instituto de Geociências da Unicamp (Carreta, 2006).

${ }^{1}$ McMullin (1987, p.50) aponta que alguns autores, como por exemplo Thomas Kunh, tenderam a enfatizar muito mais o consenso e a sua busca do que as controvérsias. O desacordo era considerado apenas periférico. Apesar dos problemas não resolvidos, propostos pelo paradigma (e para cuja resolução ele deveria fornecer instrumentos), todos operavam sobre mínima base de consenso.

${ }^{2}$ Brian Campbell (1985) também enfatiza a presença de fatores não cognitivos nas controvérsias em ciência. Em sua opinião, a ausência de informação e a incerteza não são suficientes para justificar a disputa entre cientistas. A incerteza em ciência aparece como matéria a ser negociada entre seus praticantes e não enfraquece necessariamente suas posições - não diminui, portanto, a credibilidade dos cientistas.

${ }^{3}$ Chalhoub (1996) mostra que os temores da população em relação à vacina não eram infundados ou irracionais.

${ }^{4}$ Em 1890 o doutor Jaime Silvado publicou, na revista União Médica, uma série de artigos sobre a liberdade de exercício da medicina, em que defendia o curandeirismo. Para ele, era prerrogativa da população escolher o método de cura que considerasse mais adequado. Também era contra a instituição da vacinação obrigatória, sobre a qual, devido a um estado de "anarquia mental", não haveria consenso entre os esculápios, que, incapazes de se impor pela força de seu conhecimento, recorriam à "força material das baionetas, das prisões e das multas" (Silvado,1890, p.125).

${ }^{5}$ Para exemplo desse tipo de postura, ver "A nação brasileira como grupo etnográfico e produto histórico" e "Raças que constituíram o povo brasileiro: o mestiço", de Sílvio Romero (2001a, 2001b).

${ }^{6}$ Além da epidemia de febre amarela de 1850, a cidade enfrentou, cinco anos depois, um surto de cólera. Em anos seguintes $(1868,1873$ e 1876) a febre amarela voltou a atormentar os cariocas, causando milhares de vítimas. A varíola e a peste bubônica também eram velhas conhecidas do Rio de Janeiro, visitando-o constantemente.

${ }^{7}$ Cukierman $(2007$, p.37) usa a expressão ciência desembarcada para se referir à ciência produzida no Brasil conforme os cânones europeus e que aspirava a tornar-se ciência nacional, isto é, feita no Brasil por brasileiros.

${ }^{8}$ Cruz (1904) também relacionava o material gasto nessa empreitada: 4.395 quilos e 957 gramas de piretro, 26.831 quilos e 393 gramas de enxofre, 375 litros e 725 gramas de querosene, 1.467 litros e 882 gramas de álcool, 5.121 quilos e 180 gramas de papel de calafeto, sendo de 3.134.294 metros a cubagem dos aposentos expurgados.

${ }^{9}$ Uma piada da época, veiculada em O Jornal, de outubro de 1904, sugeria que a sigla DGSP, da Diretoria Geral de Saúde Pública, significava, de fato, Dinheiro Gasto Sem Proveito.

${ }^{10}$ Para Cukierman (2007, p.97), o que se via era uma nova demarcação entre público e privado, na qual a saúde, tornada coisa pública, teria acesso irrestrito a todos os lugares, desde os mistérios da vida dos micróbios até o mais simples domicílio do Rio de Janeiro.

${ }^{11}$ Benchimol (1999) adverte, entretanto, que Oswaldo Cruz e os médicos a ele ligados eram contra a prática das desinfecções, comuns desde 1890.

${ }^{12}$ Uma análise detalhada da controvérsia sobre a descoberta do bacilo da febre amarela pode ser encontrada em Benchimol, 1999. 
${ }^{13}$ Essa premiação gerou interessante atividade: a criação de ratos para a venda. A imprensa denunciava constantemente os casos de 'vivaldinos' que viviam à custa do comércio desses animais.

${ }^{14}$ Segundo Oswaldo Cruz (1906), o índice de mortalidade dos doentes de peste tratados com o soro de Manguinhos era de apenas $17 \%$; sem o soro, variava de $60 \%$ a $95 \%$.

${ }^{15}$ A doença declinou gradualmente e atingiu seu patamar mais baixo em 1909, ano em que Cruz deixou a Diretoria. Os números de mortes pela peste nos anos seguintes (por $100 \mathrm{mil}$ habitantes) foram: 36,06 em 1904; 18,4 em 1905; 14,27 em 1906; 8,83 em 1907; 6,37 em 1908; 1,73 em 1909 (Costa, 1986, p.63).

${ }^{16}$ Há qualificada bibliografia que trata da Revolta da Vacina, a exemplo de Carvalho, 1987, Sevcenko, 1993, Chalhoub, 1996, Pereira, 2002 e Cukierman, 2007.

${ }^{17}$ Tomando como base dois períodos de cinco anos (o primeiro entre 1818 e 1822 e o segundo entre 1846 e 1850), Chalhoub (1996) mostra que o número de vacinados por mil habitantes caiu de 21,8 para 16,4. Também são significativas as porcentagens daqueles que não voltavam para observação após a vacina $(58,24 \%$ no primeiro período e $46,2 \%$ no segundo). O retorno dos vacinados era fundamental para que fosse constatada a eficácia do método e para a vacinação braço a braço, já que a inoculação dos próximos vacinados seria feita com o material das pústulas daqueles que já tinham recebido a linfa variólica. Naquele momento ainda não se utilizava a cowpox, material para vacinação extraído das pústulas de vacas contaminadas pela varíola bovina (p.112-114).

${ }^{18} \mathrm{Na}$ imprensa as opiniões estavam divididas. Jornais como Gazeta de Notícias, O Paiz e Jornal do Commercio apoiavam a medida, ao passo que o oposicionista Correio da Manhã se contrapunha ferozmente à proposta.

${ }^{19}$ Oswaldo Cruz também trocou cartas sobre a soroterapia com Jules Ogier, diretor do laboratório de Toxicologia de Paris. Arquivo COC.

${ }^{20}$ Os dois médicos também trocavam culturas para serem usadas nas experiências. Vital Brazil e Oswaldo Cruz eram amigos próximos, como atesta carta de Cruz para Vital Brazil em dezembro de 1900, em que agradecia o envio de foto de Brazil, que seria colocada em álbum destinado aos familiares e amigos íntimos (Cruz, dez.1900).

${ }^{21}$ Em carta a Oswaldo Cruz de 7 de setembro 1906, Rocha Lima contava uma história que ouvira do professor Dürck, no Instituto de Higiene de Berlim. Segundo ele, Haffkine fora perseguido porque sua vacina teria disseminado o tétano (Lima, 7 set. 1906).

${ }^{22} \mathrm{Na}$ primeira versão dessa carta, Oswaldo Cruz se manifestava contrário a aplicar a vacina em pessoas que tivessem tido contato com doentes da peste. Ele achava arriscado, pois um enfermeiro vacinado, que tratava de doentes de peste, contraíra a doença e o caso fora noticiado pelos jornais.

${ }^{23}$ Em 3 de maio de 1901, Brazil enviaria felicitações a Cruz pelo êxito do soro antipestoso e anunciaria o começo daquilo que faria a fama do Instituto Butantan: o estudo sobre soros antiofídicos (Brazil, 3 maio 1901).

${ }^{24}$ Essas observações, usadas no livro de 1902, também provinham de outros médicos, como o próprio Fajardo, Salles Guerra, Miguel Pereira, Pinto Portella e o doutorando Marques Lisboa, auxiliar do Serviço de Vacinação Antipestosa (Cruz, 1902, p.22).

${ }^{25}$ Toxemia é a intoxicação causada pela disseminação de produtos bacterianos na corrente sanguínea.

${ }^{26}$ Como ressalta Eveleen Richards (1988) em estudo sobre o controverso uso da vitamina C como tratamento alternativo para o câncer, testes clínicos sobre medicamentos dificilmente respondem a critérios objetivos e impessoais. O expert médico que faz as avaliações deve ser sempre considerado participante não imparcial. Segundo a autora, esses conflitos são "essencialmente políticos" e há sempre fatores não científicos envolvidos.

${ }^{27}$ Sobre o tema, ver também Martin, 1996, 2001b.

${ }^{28}$ Eveleen Richards (1988) também mostra que a disputa sobre os fatos científicos e a sua interpretação não são resolvidos por meio de supostas regras impessoais de procedimento experimental. Há fatores extracientíficos importantes em jogo nessa avaliação, tais como políticos e econômicos. Na controvérsia da vitamina $\mathrm{C}$ e do câncer, podem ser citados como exemplos o interesse da indústria farmacêutica, a disputa por fundos públicos para a pesquisa da doença e a manutenção da autoridade do establishment médico.

${ }^{29}$ O termo tradução significa deslocamento, traição, ambiguidade (Latour citado em Cukierman, 2007, p.59). Como afirma Cukierman, a ciência ainda estava fracamente vinculada aos destinos da nação; era 
Jorge Augusto Carreta

necessário demonstrar cabalmente que a ciência teria papel central no processo de civilização do país.

${ }^{30}$ Cortes (1993, p.98) e Cukierman (2007, p.113) relatam ter havido um 'conluio' entre a DGSP e o Instituto Manguinhos: a construção deste teria sido feita com verbas desviadas daquela repartição. Tal versão é mencionada também por Aragão (1950, p.18) em sua "Notícia histórica sobre a fundação do do Instituto Oswaldo Cruz". Afirma ele que a construção do castelo em estilo mourisco se fez com 'sobras' da DGSP.

${ }^{31}$ Cukierman (2007, p.81-82, nota 7) transcreve os dados utilizados por Oswaldo Cruz no relatório de 1903 da Diretoria, em uma discussão sobre a eficácia do soro antipestoso. Em um dos quadros estão os números do uso do preparado em pacientes de Santos, em 1900, coligidos por Vitor Godinho e publicados na Revista Médica de São Paulo, n.7, de 15 de junho de 1900. O uso do soro parece ter sido bem-sucedido (37,5\% de mortalidade para o soro de Terni e $36,84 \%$ para o soro de Yersin), mas o número de pacientes tratados era muito pequeno para ter relevância estatística, como admitiu o próprio Cruz no mesmo documento.

32 De acordo com Stepan (1976, p.148), para obter reconhecimento como instituição de ciência básica e aplicada, Manguinhos teria assumido funções normalmente desempenhadas pelas instituições estrangeiras congêneres, como o Instituto Pasteur. Isso incluiria recrutamento e treinamento de cientistas, criação de relacionamento do tipo 'cliente' com o governo e outros órgãos que pudessem utilizar os conhecimentos produzidos pelo Instituto e, por fim, desenvolvimento de um programa de pesquisas exequível, que atendesse às necessidades do país e, ao mesmo tempo, se desvinculasse das questões locais. Cortes (1993, p.121), por sua vez, afirma que o ensino desenvolvido em Manguinhos não tinha o objetivo exclusivo de formar pesquisadores, mas também procurava difundir a 'ideologia pastoriana'.

${ }^{33}$ Segundo Aragão (1950, p.22), Oswaldo se referia a seu grupo como jardim de infância da ciência, uma alusão à pouca idade da maioria de seus discípulos e também, seguramente, porque os considerava pioneiros de um novo modo de fazer ciência no Brasil.

\section{REFERÊNCIAS}

ARAGÃO, Henrique Rohan Beaupierre.

Notícia histórica sobre a fundação do IOC. Memórias do Instituto Oswaldo Cruz, Rio de Janeiro, v.48. Disponível em: http:// memorias.ioc.fiocruz.br/pdf/Tomo48/ tomo48(fu)_1-50.pdf. Acesso em: 3 maio 2011. 1950.

BENCHIMOL, Jaime.

Dos micróbios aos mosquitos: febre amarela e a revolução pasteuriana no Brasil. Rio de Janeiro: Ed. Fiocruz. 1999.

BENCHIMOL, Jaime.

Pereira Passos, um Haussmann tropical: a renovação urbana do Rio de Janeiro no início do século XX. Rio de Janeiro: Departamento Geral de Documentação e Informação Cultural. 1992.

BENCHIMOL, Jaime (Coord.).

Manguinhos: do sonho à vida. Rio de Janeiro: Casa de Oswaldo Cruz. 1990.

BESREDKA, Alexandre.

Carta a Oswaldo Cruz. Rio de Janeiro. Fundo Oswaldo Cruz, série Correspondência, subsérie Científica, dôssie 7, BR RJCOC OC-COR-CI-07 (Casa de Oswaldo Cruz/Fiocruz). 30 dez. 1889.

BRAZIL, Vital.

Carta a Oswaldo Cruz. Rio de Janeiro. Fundo
Oswaldo Cruz, série Correspondência, subsérie Científica, dôssie 5, BR RJCOC OC-COR-CI-05 (Casa de Oswaldo Cruz/Fiocruz).

3 maio 1901.

BRAZIL, Vital.

Carta a Oswaldo Cruz. Rio de Janeiro. Fundo Oswaldo Cruz, série Correspondência, subsérie Científica, dôssie 5, BR RJCOC OC-COR-CI-05 (Casa de Oswaldo Cruz/Fiocruz). 28 mar. 1901.

BRAZIL, Vital.

Carta a Oswaldo Cruz. Rio de Janeiro. Fundo Oswaldo Cruz, série Correspondência, subsérie Científica, dôssie 5, BR RJCOC OC-COR-CI-05 (Casa de Oswaldo Cruz/Fiocruz). 5 jun. 1900.

BRAZIL, Vital.

Carta a Oswaldo Cruz. Rio de Janeiro. Fundo Oswaldo Cruz, série Correspondência, subsérie Científica, dôssie 5, BR RJCOC OC-COR-CI-05 (Casa de Oswaldo Cruz/Fiocruz). 9 dez. 1899.

CAMPBELL, Brian L.

Uncertainty as symbolic action in dispute among experts. Social Studies of Science, London, v.15, n.3, p.429-453. 1985.

CARRETA, Jorge Augusto.

'O micróbio é o inimigo': debates sobre a microbiologia no Brasil (1885-1904). Tese (Doutorado) - Programa de Pós-graduação em 
Política Científica e Tecnológica, Universidade Estadual de Campinas, Campinas. 2006.

CARVALHO, José Murilo de. Os bestializados: o Rio de Janeiro e a República que não foi. São Paulo: Companhia das Letras. 1987.

CHALHOUB, Sidney.

Cidade febril: cortiços e epidemias na corte imperial. São Paulo: Companhia das Letras. 1996.

CORTES, Bianca Antunes.

Mestres e aprendizes: a iniciação do cientista em Manguinhos nos tempos de Oswaldo - 1900/ 1915. Dissertação (Mestrado) - Faculdade de Educação, Universidade Federal Fluminense, Niterói. 1993

COSTA, Nilson Rosário.

Lutas urbanas e controle sanitário: origens das políticas de saúde no Brasil. Petrópolis: Vozes. 1986.

CRUZ, Oswaldo.

Carta a Émile Marchoux. Rio de Janeiro. Fundo Oswaldo Cruz, série Correspondência, subsérie Científica, dossiê 15, BR RJCOC OC-COR-CI-15 (Casa de Oswaldo Cruz/Fiocruz). 15 jan. 1907.

CRUZ, Oswaldo Gonçalves.

Relatório apresentado ao Exmo. Sr. Dr.

Augusto Tavares de Lyra, Ministro da Justiça e

Negócios Interiores, pelo Dr. Oswaldo

Gonçalves Cruz, Diretor-Geral de Saúde

Pública, 1906. Rio de Janeiro: Imprensa

Nacional. 1907.

CRUZ, Oswaldo.

Carta a Henrique Rocha Lima. Rio de Janeiro. Fundo Oswaldo Cruz, série Correspondência, subsérie Científica, dossiê 11, BR RJCOC OCCOR-CI-11 (Casa de Oswaldo Cruz/Fiocruz). 31 dez. 1906.

CRUZ, Oswaldo.

Carta a Henrique Rocha Lima. Rio de Janeiro. Fundo Oswaldo Cruz, série Correspondência, subsérie Científica, dossiê 11, BR RJCOC OCCOR-CI-11 (Casa de Oswaldo Cruz/Fiocruz). 21 nov. 1906.

CRUZ, Oswaldo Gonçalves.

Relatório apresentado ao Exmo. Sr. J.J. Seabra, Ministro da Justiça e Negócios Interiores, pelo dr. Oswaldo Gonçalves Cruz, Director Geral de Saúde Pública, 1905. Rio de Janeiro: Imprensa Nacional. 1906.

CRUZ, Oswaldo Gonçalves.

Relatório apresentado a Sua Ex. o Sr. Ministro de Estado da Justiça e Negócios Interiores pelo Diretor-Geral de Saúde Pública, 1903. Rio de Janeiro: s.n. [1904].
CRUZ, Oswaldo.

Dos acidentes em soroterapia. Rio de Janeiro:

Typ. Bernard Freres. 1902.

CRUZ, Oswaldo.

Carta a Miguel Pereira. Rio de Janeiro. Fundo Oswaldo Cruz, série Correspondência, subsérie Científica, dossiê 13, BR RJCOC OC-COR-CI-13. (Casa de Oswaldo Cruz/Fiocruz). 21 nov. 1901.

CRUZ, Oswaldo.

Carta a Vital Brazil. Fundo Oswaldo Cruz, série Correspondência, subsérie Científica, dôssie 5, BR RJCOC OC-COR-CI-05 (Casa de Oswaldo Cruz/Fiocruz). 27 fev. 1901.

CRUZ, Oswaldo.

Carta a Vital Brazil. Rio de Janeiro. Fundo

Oswaldo Cruz, série Correspondência, subsérie Científica, dôssie 5, BR RJCOC OC-COR-CI-05 (Casa de Oswaldo Cruz/Fiocruz). dez. 1900.

CRUZ, Oswaldo.

Carta a Vital Brazil (segunda versão). Rio de Janeiro. Fundo Oswaldo Cruz, série

Correspondência, subsérie Científica, dôssie 5, BR RJCOC OC-COR-CI-05 (Casa de Oswaldo Cruz/Fiocruz). 14 jun. 1900.

CUKIERMAN, Henrique.

Yes, nós temos Pasteur: Manguinhos, Oswaldo Cruz e a história da ciência no Brasil. Rio de Janeiro: Relume Dumará. 2007.

DEL SESTO, Steven.

Use of knowledge and values in technical controversy: the case of nuclear reactor safety in the US. Social Studies of Science, London, v.13, p.395-416. 1983.

GIERE, Ronald N.

Controversies involving science and technology: a theoretical perspective. In: Engelhardt Jr., H. Tristam; Caplan, Arthur L. (Ed.). Scientific controversies: case studies in the resolution and closure of disputes in science and technology. New York: Cambridge University Press. p.125-150. 1987.

LATOUR, Bruno.

The pasteurization of France. Massachusetts: Harvard University Press. 1988.

LAW, John.

Le laboratoire et ses réseaux. In: Callon, Michel (Ed.). La science et ses réseaux. Paris: La Découverte. p.117-148. 1989.

LIMA, Henrique da Rocha.

Carta a Oswaldo Cruz. Rio de Janeiro. Fundo Oswaldo Cruz, série Correspondência, subsérie Científica, dossiê 11, BR RJCOC OC-COR-CI-11 (Casa de Oswaldo Cruz/Fiocruz). 7 set. 1906. 
MACHADO, Roberto et al.

Danação da norma: medicina social e constituição da psiquiatria no Brasil. Rio de Janeiro: Graal. 1978.

\section{MARTIN, Brian.}

The politics of a scientific meeting: the originof-Aids debate at the Royal Society. Politics and the Life Sciences, Bloomington, v.20, n.2, p.119130. 2001a.

\section{MARTIN, Brian.}

The burden of poof and the origin of acquired immune deficiency syndrome. Philosophical

Transactions of the Royal Society of London, London, series B, v.356, p.939-944. 2001b.

MARTIN, Brian.

Sticking a needle into science: the case of polio vaccines and the origin of Aids. Social Studies of Science, London, v.26, n.2, p.245-276. 1996.

MCMULLIN, Ernan.

Scientific controversy and its termination. In: Engelhardt Jr., H. Tristam; Caplan, Arthur L. (Ed.). Scientific controversies: case studies in the resolution and closure of disputes in science and technology. New York: Cambridge University Press. p.49-91. 1987.

MENDELSOHN, Everett.

The political anatomy of controversy in sciences. In: Engelhardt Jr., H. Tristam; Caplan, Arthur L. (Ed.). Scientific controversies: case studies in the resolution and closure of disputes in science and technology. New York:

Cambridge University Press. p.93-124. 1987.

NELKIN, Dorothy.

Controversy: politics of technical decision. Newbury Park: Sage. 1992.

NELKIN, Dorothy.

Controversies and the authority of science. In: Engelhardt Jr., H. Tristam; Caplan, Arthur L. (Ed.). Scientific controversies: case studies in the resolution and closure of disputes in science and technology. New York: Cambridge University Press. p.283-293. 1987.

NOWOTNY, Helga.

Controversies in science: remarks on the different modes of production of knowledge and their use. Zeitschrift für Sociologie, Bielefeld, Jg.4, Heft1, S.34-45. 1975.

PEREIRA, Leonardo A.M.

As barricadas da saúde: vacina e protesto popular no Rio de Janeiro da Primeira República. São Paulo: Ed. Fundação Perseu Abramo. 2002.
PEREIRA, Miguel.

Carta a Oswaldo Cruz. Rio de Janeiro. Fundo Oswaldo Cruz, série Correspondência, subsérie Científica, dossiê 13, BR RJCOC OC-COR-CI-13 (Casa de Oswaldo Cruz/Fiocruz). 7 nov. 1901.

\section{PRÉVOST, Chapot.}

Carta a Francisco Fajardo. Fundo Oswaldo Cruz, série Correspondência, subsérie Científica, dossiê 2, BR RJCOC OC-COR-CI-02 (Casa de Oswaldo Cruz/Fiocruz). 11 fev. 1902.

\section{RICHARDS, Eveelen.}

The politics of therapeutic evaluation: the vitamin $\mathrm{C}$ and cancer controversy. Social Studies of Science, London, v.18, p.653-701. 1988.

ROMERO, Sílvio.

A nação brasileira como grupo etnográfico e produto histórico. In: Romero, Sílvio. História da literatura brasileira. Rio de Janeiro: Imago. t.1, p.99-103. 2001a.

ROMERO, Sílvio.

Raças que constituíram o povo brasileiro: o mestiço. In: Romero, Sílvio. História da literatura brasileira. Rio de Janeiro: Imago. t.1, p.105-121. 2001b.

SAMPAIO, Gabriela dos Reis.

Nas trincheiras da cura: as diferentes medicinas no Rio de Janeiro imperial. Campinas: Ed. da Unicamp. 2002.

SANT'ANNA, Vanya.

Ciência e sociedade no Brasil. São Paulo: Símbolo. 1978.

SEVCENKO, Nicolau.

A Revolta da Vacina: mentes insanas em corpos rebeldes. São Paulo: Scipione. 1993.

SILVADO, Jaime.

A obrigatoriedade da vacinação perante a liberdade espiritual. União Médica, Rio de Janeiro, n.4, p.121-128. 1890.

\section{STEPAN, Nancy.}

Gênese e evolução da ciência brasileira: Oswaldo Cruz e a política de investigação científica e médica. São Paulo: Artenova. 1976.

VELHO, Lea; VELHO, Paulo.

A controvérsia sobre o uso de alimentação alternativa no combate à subnutrição no Brasil. História, Ciências e Saúde - Manguinhos, Rio de Janeiro, v.9, n.1, p.125-57. 2002.

VIDAL, Gil.

Applicação macabra. Correio da Manhã, Rio de Janeiro, 15 jul. 1904.

\section{$\rightarrow \rightarrow \rightarrow<<$}

